\title{
SHIFTS IN MICROBIAL COMMUNITY STRUCTURE COULD BE LINKED TO WEATHER ANOMALIES? A CASE STUDY ON CACHAÇA (SUGARCANE DISTILLED SPIRIT) FERMENTATION
}

\author{
Cauré Barbosa Portugal ${ }^{1}$, Sandra Helena da Cruz ${ }^{1}$, Fernando Dini Andreote ${ }^{1}$ \\ ${ }^{1}$ University of São Paulo - ESALQ/USP, E-mail: caure.portugal@usp.br, shcruz@usp.br, fdandreo@usp.br
}

\section{ABSTRACT}

Weather anomalies like high temperatures combined to long drought periods have frequently coincided with sluggish and spoiled fermentations in Brazilian cachaça distilleries. In this study, we compared the beginning of spontaneous fermentation in local processes to figure out which factors are distinctive and might be influencing fermentation in consecutive years with different weather conditions. We assessed two producing units in Southeast Brazil in 2013-2014, and daily analyzed two cases of spontaneous fermentation, considering molecular profile and the dynamics of microbial communities, as well as physicochemical parameters of the medium. Weather data were also collected. Atypical microbial community shifts and dominance of spoilage microorganisms were observed in 2014. The sugarcane juice also presented lower concentration of assimilable nitrogen in 2014 in association to lower ethanol yield. Compared to the last 20 -year average, the rainfall was 7.5 times lower, in addition to general elevation of temperature $\left(+3^{\circ} \mathrm{C}\right)$. Those bioprocesses influenced by lengthy droughts and higher temperatures disclose microbial communities defined by dominance and persistence of less demanding yeasts and overgrowth of bacterial populations. Also, the lack of nitrogen sources seems to be one of the major causes of biomass yield reduction, lagging sugar consumption by yeasts, and consequent spoilage activity.

Keywords: Distilled beverage, microbial ecology, spoilage, climate anomaly 


\section{ALTERAÇÕES NA ESTRUTURA DE COMUNIDADES MICROBIANAS PODEM ESTAR RELACIONADAS COM ANOMALIAS CLIMÁTICAS? UM ESTUDO DE CASO EM FERMENTAÇÕES DE CACHAÇA}

\section{RESUMO}

Anomalias climáticas, incluindo altas temperaturas combinadas a longos períodos de seca, têm apresentado frequente correspondência com lentidão e contaminação de fermentações em destilarias de cachaça no Brasil. Neste estudo, comparou-se o início de fermentações espontâneas em produções locais para compreender quais fatores podem ser distintivos e influenciar a fermentação em anos consecutivos com diferentes características climáticas. Monitoraram-se duas unidades produtoras na região Sudeste do Brasil em 2013-2014 e analisaram-se diariamente dois casos de fermentação espontânea considerando perfil molecular e dinâmica das comunidades microbianas, assim como alguns parâmetros físico-químicos do meio. Dados climáticos também foram coletados. Observaram-se alterações atípicas nas comunidades microbianas e dominância de microrganismos contaminantes em 2014. O caldo de cana apresentou baixa concentração de nitrogênio assimilável associado com baixo rendimento fermentativo. Em comparação com os últimos 20 anos, a taxa de precipitação foi 7,5 vezes mais baixa nesse ano, além de tendência de elevação geral das temperaturas $\left(+3^{\circ} \mathrm{C}\right)$. Estes bioprocessos influenciados por longos períodos de seca e altas temperaturas parecem favorecer comunidades microbianas definidas por dominância e persistência de leveduras menos exigentes nutricionalmente e maior expressão de populações bacterianas. Além disso, a falta de nitrogênio no meio parece ser uma das principais causas da redução de biomassa celular, lento consumo dos açúcares pelas leveduras e favorecimento de contaminações.

Palavras-chave: Bebida destilada, ecologia microbiana, contaminação, anomalia climática

\section{INTRODUCTION}

Cachaça is the typical and exclusive designation of the Brazilian sugarcane distilled spirit, obtained by fresh sugarcane juice. The origins of this distilled spirit date back to the Brazilian colonial period, in the sixteenth century, and even with the latter intense industrial progress in the sector, the craft production still accounts for nearly 300 million liters per year (VERDI, 2006). The production of cachaça in the craft segment is usually performed in family businesses, whose 
management practices are often linked to regional traditions that today still reproduce outdated practices that sometimes may be related to quality impairment of the distilled spirit.

The craft distilleries, as in the custom, process the fermentation of sugarcane juice from a homemade starter culture, ordinarily known as 'fermento caipira' (in Portuguese, something like 'farmland organized ferment'), a practice that consists on the prospection of wild yeasts that is commonly grounded on empirical and regional recipes (LEA \& PIGGOTT, 2003). This kind of 'free-range' starter culture is prepared by daily addition of fresh and diluted sugarcane juice with the aim of gradually increase the concentration of the medium (MORAIS et al., 1997). Precisely by the involvement of several autochthonous microorganisms, this kind of spontaneous fermentation may produce cachaças with higher aromatic complexity, associated to fruity, floral character, and an overall positive organoleptic sensation (PORTUGAL et al., 2016). However, the occurrence of sluggish or stuck fermentation is not rare, and many times it results in early spoilage of the sugarcane juice by undesirable microorganisms. The causes that lead to slow and incomplete fermentation may be diverse and include high osmotic pressure, extreme temperatures, the presence of inhibitory substances, ethanol stress, and nitrogen shortage of the sugarcane juice (MUNOZ \& INGLEDEW, 1989). On the other hand, inadequate processing practices and sanitation procedures also induce the overgrowth of resident bacterial communities, which is also reported as a possible cause of yeast cell inhibition (HUANG et al., 1996).

Additionally, some recent evidence about the effects of abnormal weather patterns on agriculture has shown that the trends of increasing temperatures and carbon dioxide concentration may affect the soil moisture, as well as the influence and frequency of high temperatures, floods, and droughts in different areas (MARIN \& NASSIF, 2013). Current studies in viticulture, for example, demonstrated that those factors may be directly altering the microbial communities associated to plants and enhancing the propensity to pathogen attack (BOKULICH et al., 2014, HANNAH et al., 2013). In the case of regular sugarcane growing areas, in turn, the structure of microbial communities seems to be highly influenced by the territory and could show a weaker correlation to climate variables (GUMIERE et al., 2016). However, weather anomalies are supposed to modify those systems and dictate stronger selection events, distancing populations and shifting the microbial community patterns in those affected environments (BOKULICH et al., 2014). Recent studies have found that in sugarcane expanding zones, the intense moisture stress may lead to lower productivity and increased occurrence of infections that will negatively impact 
on the quality of the juice (SENGAR et al., 2014). One of the most relevant parameters that will influence both the fermentation process and the chemical quality of the distilled spirit is the content of yeast assimilable nitrogen, which can be affected by water holding efficiency and the direct extent of the rhizosphere (VERDENAL et al., 2014).

During the 2014 sugarcane harvest, several cases of sluggish and spoiled fermentations in cachaça distilleries were reported in the Southeast region of Brazil. That year was characterized by unusual higher temperatures and very low precipitation rates (IAG/USP, 2014), suggesting that those factors would be inducing unexpected shifts in the microbial community structure and leading to uncommon spoilage fermentations. Considering that context, the aim of this study was to collect and analyze microbial, physicochemical and weather parameters in two local producing units in a locality of Southeast Brazil to find out possible differences in two consecutive years (2013-2014). We monitored and analyzed the fermentation processes during the first nine days of the starter culture formation, attempting to bring preliminary evidences of which factors may be distinctive and influence the fermentation under different weather conditions.

\section{MATERIAL AND METHODS}

In this preliminary study, we had the opportunity to monitor two craft distillery processes in the locality of Piracicaba, Brazil. One fermentation (process A) was monitored during October 2013 (considered as control, and under typical weather conditions), whereas two other preparations were assessed during October 2014 (processes B and C). The producers used the same sugarcane variety (var. SP 81-3250) and the same production procedures, as described below. The sugarcane stalks were previously defoliated, crushed, and the juice was briefly decanted to eliminate solid particles and grainy dirtiness. The starter culture was prepared as follows: an initial volume (10 L) of sugarcane juice was diluted to $6^{\circ} \mathrm{Bx}$ (degrees Brix); then, fresh sugarcane juice was added to the vat, doubling the volume and progressively increasing the sugar concentration in 2 Brix-units $(6$, $\left.8,10,12,14^{\circ} \mathrm{Bx}\right)$ to each 24 -hour interval. In the sixth day the vat was completed up to the tank's useful volume (100 liters), adjusting the final concentration of the must in $16^{\circ} \mathrm{Bx}$ and letting it rest until the end of fermentation. The vats had no sealing cap, nor temperature control (as usual in most of the cachaça production processes). Samples were taken in sterile tubes every day and quickly processed for microbiological analysis, or frozen $\left(-20^{\circ} \mathrm{C}\right)$ for further physicochemical analyses. Sampling and analysis were always carried out by duplicates. 


\section{Microbiological and molecular analyses}

The samples were serially diluted in sterile saline solution $(0.15 \mathrm{M} \mathrm{NaCl})$ and plated on different selective media for the assessment of both bacteria and yeast populations. WLN medium (Becton Dickinson \& Co., France) with $100 \mathrm{mg} \mathrm{l}^{-1}$ chloramphenicol (Neo Química, Brazil) was used for total yeasts counting; and Lysine-agar (Oxoid, England) with chloramphenicol (100 $\mathrm{mg} \mathrm{l}^{-}$ 1) for non-Saccharomyces yeasts. MRS agar (Merck, Germany) plus $100 \mathrm{mg} \mathrm{l}^{-1}$ nystatin (Nova Química, Brazil) was employed for lactic acid bacteria; and Mannitol-agar [5 $\mathrm{g} \mathrm{l}^{-1}$ yeast extract (Merck), $3 \mathrm{~g} \mathrm{l}^{-1}$ peptone (Becton Dickinson \& Co., France), $25 \mathrm{~g} \mathrm{l}^{-1} \mathrm{D}$-mannitol (Inlab, Brazil), 20 $\mathrm{g}^{-1}$ agar (Merck, Germany), $100 \mathrm{mg} \mathrm{l}^{-1}$ nystatin], for acetic acid bacteria.

For yeast identification, the colonies grown on WL medium were analyzed under a stereomicroscope, characterized and initially separated by morphotypes. Six colonies of each morphotype were isolated and genomic DNA extracted using Wizard Genomic DNA kit (Promega). The genetic material was analyzed by PCR reaction based on the rRNA gene 26S (D1/D2 domain), using the primers NL-1 and NL-4, as previously described by Kurtzman \& Robnett (1998). The amplified products were purified and processed by Sanger sequencing in the Lab. Animal Biotechnology ("Luiz de Queiroz" College of Agriculture, Piracicaba, São Paulo state, Brazil). The sequencing result was further analyzed with the software Chromas-Pro (v. 2.6; Technelysium Pty Ltd., Australia), and the BLASTn search tool (National Library of Medicine, National Center for Biotechnology Information [http://blast.ncbi.nlm.nih.gov/blast]) was used for comparison with sequences included in the GenBank database (NCBI [http://www.ncbi.nlm.nih.gov/genbank]) for species determination. Sequences were deposited in the GenBank database for public availability.

Once quantification and identification of the yeast species was completed, we evaluated different diversity indexes to compare the profile of yeast populations of each fermentation assessed.

\section{Terminal restriction fragment length polymorphism analysis (T-RFLP)}

Total genomic DNA was extracted after two-cycle centrifugation $(14,000 \times \mathrm{g}, 5 \mathrm{~min})$ of 1.5 $\mathrm{ml}$ of fermenting sugarcane juice. Isolation was performed using the PowerSoil DNA kit (MoBio, Carlsbad, USA) and a PowerLyzer benchtop homogenizer (MoBio). The DNA samples were quantified, and the quality assessed in a NanoDrop spectrometer. A volume of $1.0 \mu l$ 
(approximately $50 \mathrm{ng}$ ) was used for PCR reactions. For the characterization of fungal communities, the DNA amplification was performed with ITS specific primers FAM-ITS1F (GARDES \& BRUNS, 1993) and ITS4 (WHITE et al., 1990). Reactions were carried out in $50 \mu 1$, with $1 \times$ PCR buffer, $3 \mathrm{mM} \mathrm{MgCl} 2,0.2 \mathrm{mM}$ of each dNTP, 20 pmol of both primers, $2.5 \mathrm{U}$ Taq DNA Polymerase (Invitrogen, Brazil), with the conditions previously described by Gardes \& Bruns (1993). Endonuclease digestion, restriction reactions, and analysis of results were performed according to Gumiere et al. (2016). Bacterial community fingerprints used the $16 \mathrm{~S}$ rDNA primers FAM*-8fm and 1404R-Eub (CULMAN et al., 2008). Endonuclease cleavage, restriction reactions, and analysis of results were carried out as described by Durrer et al. (2017). Intensity peaks patterns were used for principal coordinate analysis with software PAST3 (HAMMER et al., 2001). Cluster analysis was performed by ranked Pearson correlation and neighbor-joining method with Bionumerics 7 software platform (Applied Maths, Sint-Martens-Latem).

\section{Chemical analyses}

To determine the ethanol content, $25 \mathrm{ml}$ of each sample processed in a microdistiller TE012 (Tecnal, Piracicaba) was analyzed in a digital densitometer DMA-4500 (Anton Paar, Austria). Total acidity analysis was determined by sodium hydroxide titration, as described by Caldas (1998). Reducing sugars were determined by the 3,5-dinitrosalicylic acid (DNS) colorimetric method, according to Miller (1959), with modifications: mix $500 \mu$ l of the sample with $500 \mu \mathrm{l}$ of the DNS reagent (Prozyn, São Paulo), boil 5 min, cool down and makeup with distilled water up to $5 \mathrm{ml}$, and determine the absorbance at $540 \mathrm{~nm}$. Yeast assimilable nitrogen (YAN) was estimated by the Sorensen's formaldehyde titration method (ZOECKLEIN et al., 1995), taking $10 \mathrm{ml}$ of the

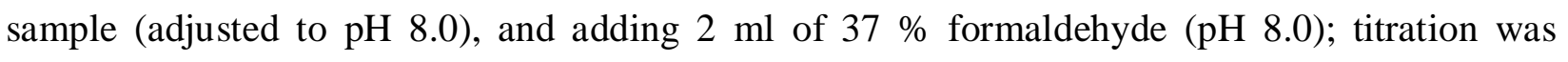
performed with $0.05 \mathrm{~N} \mathrm{NaOH}$ until $\mathrm{pH} 8.0$, and YAN concentration expressed in $\mathrm{mg} \mathrm{N}^{-1}$.

\section{Accession number of sequences deposited in the GenBank database}

The following GenBank accession numbers are registered: Meyerozyma guilliermondii (KR014233, KR558712, KR558719, KR558720, KR558722, KR558723), Hanseniaspora guilliermondii (KR014234, KR014235, KR014236), Hanseniaspora opuntiae (KR558721), Hanseniaspora vineae (KR558711, KR558726), Issatchenkia terricola (KR558715), Pichia 
fermentans (KR558714, KR558718, KR014237), Pichia kudriavzevii (KR558724), S. cerevisiae (KR014238, KR014239, KR014240, KR014241, KR558716, KR558717, KR558725).

\section{Weather data collect}

Climatological charts were obtained from the public Brazilian database Weather Forecasting and Climate Studies Center/ National Institute for Space Research (CPTEC-INPE, Brazil), and the parameters considered in this study were: (a) accumulated precipitation; (b) precipitation anomalies; (c) maximum temperature anomalies. Regional weather data from the municipality of Piracicaba, in the São Paulo state, were collected from the Meteorological Station of College of Agriculture 'Luiz de Queiroz' (Piracicaba, São Paulo state, Brazil). The results depict only the month of October, in both 2013 and 2014.

\section{Diversity estimation}

The following calculations were considered: species richness $(\mathrm{S})$, Shannon index $\left(\mathrm{H}^{\prime}\right)$, Pielou's evenness index (P) and Berger-Parker dominance index (d). The software DivEs v. 4.0 (RODRIGUES, 2017) was employed for the ecological estimations using base-10 logarithm of colony counting of each yeast morphotype/species.

\section{RESULTS}

\section{Weather traits in different years}

Table 1 summarizes climatological parameters in the locality of Piracicaba, showing that conditions in October 2013 presented the same trend recorded for the last 20-year average. In contrast, temperatures in October 2014 were around $+3^{\circ} \mathrm{C}$ higher, combined to a seven-fold lower precipitation rate $(20 \mathrm{~mm})$ in addition to reduced relativity humidity $(55 \%)$, as well as prominent insolation and evaporation values.

Table 1. Climatological data for Piracicaba, São Paulo State, Brazil, in October 2013 and 2014.

\begin{tabular}{|c|c|c|c|c|c|c|c|c|}
\hline & \multicolumn{3}{|c|}{ Temperature $\left({ }^{\circ} \mathrm{C}\right)$} & \multirow{2}{*}{$\mathbf{P}(\mathbf{m m})$} & \multirow{2}{*}{$\mathbf{E}(\mathbf{m m})$} & \multirow{2}{*}{ rH (\%) } & \multirow{2}{*}{ rD } & \multirow{2}{*}{ I (h/d) } \\
\hline & max. & min. & $\overline{\mathbf{x}}$ & & & & & \\
\hline 2013 (October) & 29.9 & 16.8 & 23.3 & 153.6 & 5.58 & 71 & 12 & 7.8 \\
\hline 2014 (October) & 32.5 & 16.7 & 26.6 & 20.1 & 8.82 & 55 & 5 & 9.7 \\
\hline 20-year average ${ }^{a}$ & 29.9 & 17.0 & 23.5 & 115.59 & 5.36 & 74 & 11 & 6.6 \\
\hline
\end{tabular}




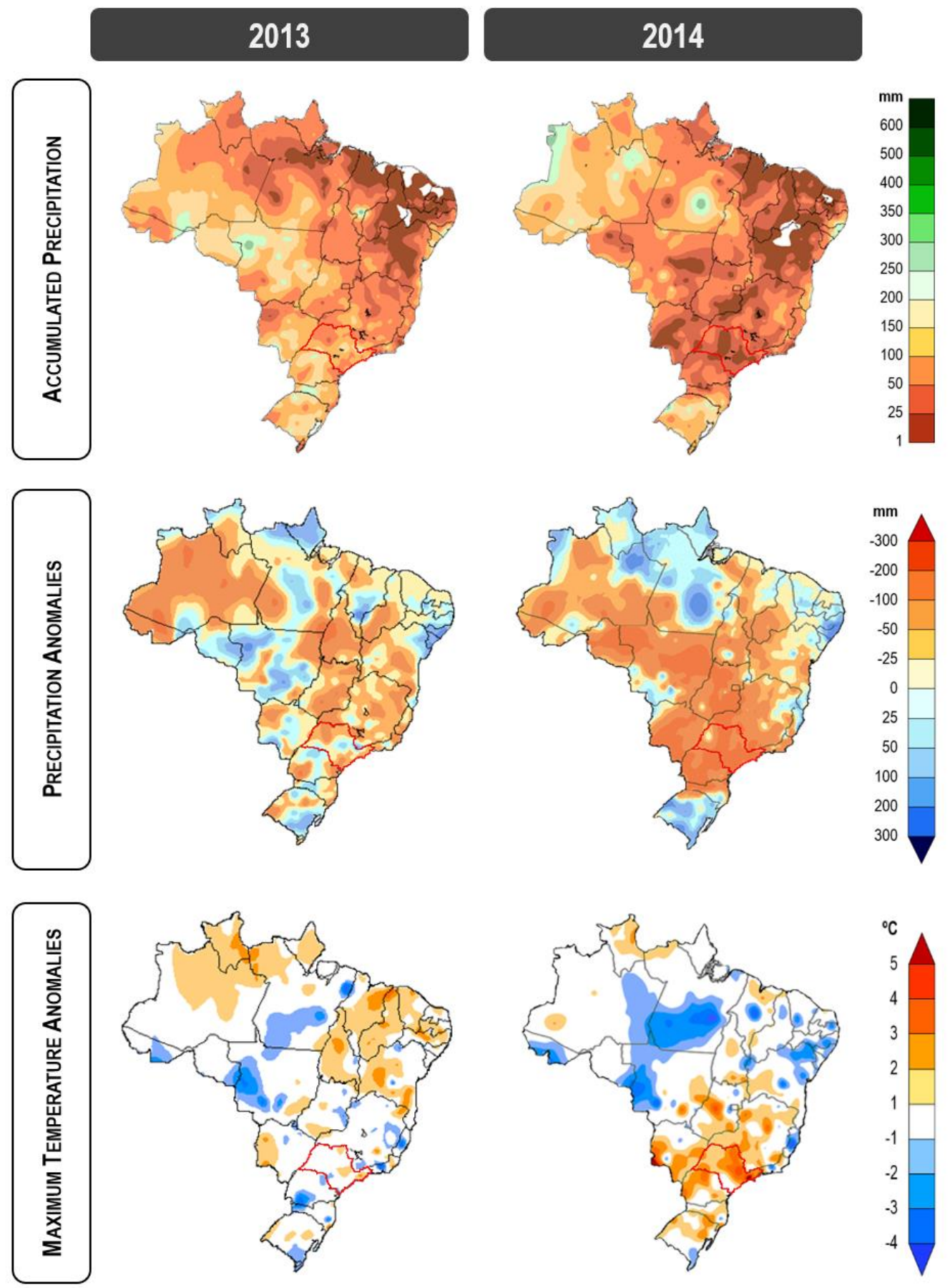

Figure 1. Climatological maps of the Brazilian territory. Maps indicate, respectively: accumulated precipitation, precipitation anomalies, and maximum temperature anomalies. Redcircled region corresponds to São Paulo State. Charts refer to October 2013 and October 2014. Source: Weather Forecasting and Climate Studies Center/ National Institute for Space Research (CPTEC-INPE, Brazil). 


\section{Physicochemical parameters}

Figure 2 (Table S1, S2, S3) depicts the evolution of some chemical parameters over nine consecutive days in the fermentations assessed, including total reducing sugars, ethanol and yeast assimilable nitrogen (YAN). Ups and downs in the sugar content (Figure 2a) for each system are normal in those cases of spontaneous fermentation, because at the same time there is daily addition of fresh juice (as done in many traditional distilleries), microbial activity is progressively growing and therefore there is continuous sugar consumption. But it is worth noting that in fermentation ' $A$ ' (2013), the decrease in the concentration of reducing sugars is noticeably more intense from day 6 when compared to the process ' $\mathrm{B}$ ' and ' $C$ ' (2014) (the polynomial trendlines in the same chart show the attenuation differences for simple comparison). The ethanol yield after nine days (Figure 2b) was inversely proportional to the sugar consumption rates observed. Further, the batch "C" shows a stronger raise in ethanol already at day three, but in fact, both fermentations carried out 2014 showed low fermentative activity, with a final yield below $4 \%\left(\mathrm{v} \mathrm{v}^{\mathbf{- 1}}\right)$ ethanol after nine days. It is also important to highlight that the assimilable nitrogen levels during the ferment formation in batch ' $A$ ' ranged from 140 to $114 \mathrm{mg} \mathrm{l}^{-1}$ (Figure 2c), coinciding with subsequent hydrolysis of sucrose (indicated by a decrease in total reducing sugar levels in Figure 2a). Such traits indicated an efficient uptake of simple sugars during the spontaneous fermentation, as well as the prompt conversion to ethanol nine days after the beginning of the process. However, YAN concentrations - which include free amino nitrogen, ammonia, and ammonium - during the ferment formation did not exceed $78 \mathrm{mg} \mathrm{l}^{-1}$ in batch ' $\mathrm{B}$ ', and $34 \mathrm{mg} \mathrm{l}^{\mathbf{- 1}}$ in batch ' $\mathrm{C}$ '. Total acidity did not exceed $0.9 \mathrm{~g} \mathrm{l}^{-1}$ (acetic acid) in all cases and it seemed not to be a distinctive indicator in our assays. The final $\mathrm{pH}$ values uncovered after nine days were 3.57, 4.07 and 4.15, respectively, in fermentation A, B and C (Table S1, S2, S3). 

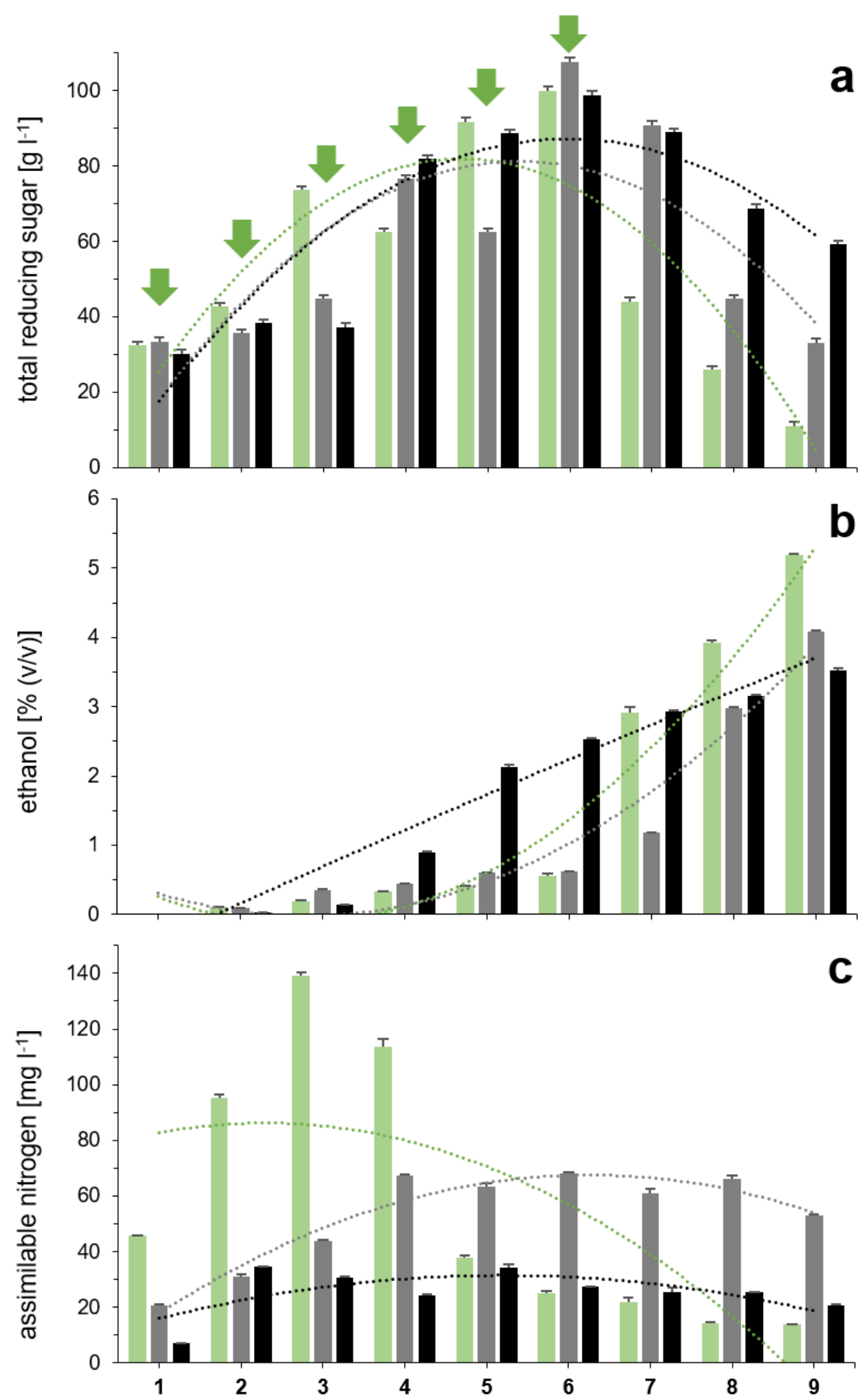

Figure 2. Chemical parameters of sugarcane juice during spontaneous fermentations. (a) Total reducing sugar concentration $\left(\mathrm{g} \mathrm{l}^{-1}\right)$; (b) ethanol $\left(\%\right.$ in $\left.\mathrm{v} \mathrm{v}^{-1}\right)$; (c) assimilable nitrogen (mg N $\left.{ }^{-1}\right)$. fermentation 'A' (2013); - fermentation 'B' (2014); $\mathbf{\square}$ fermentation ' $C$ ' (2014). Dotted lines are order-2 polynomial trendlines of each corresponding fermentation process. Green arrows indicate sequential addition of fresh sugarcane juice during the first six days and correspond to the starter culture formation stage. 


\section{Microbial community structure}

The dynamics of the microbial communities (counting of total yeast, acetic bacteria and lactic bacteria) and the proportional abundance of the yeast species identified in this study during nine days are represented in Figure 3 (Table S1, S2, S3). An early settlement of two apiculate yeast species characterized the fermentation 'A', namely Meyerozyma guilliermondii and Hanseniaspora guilliermondii (Figure 3a2), followed by later dominance of wild S. cerevisiae during tumultuous fermentation (corresponds to the fourth day on). Both acetic and lactic bacteria counting reached up to $10^{7}$ and $10^{8} \mathrm{CFU} \mathrm{ml}^{-1}$ (colony forming unit per ml) (Figure 3a1), and those microbial populations took part actively in the process until the end of fermentation. On the other hand, both fermentations carried out in 2014 showed that bacteria densely colonized the medium from the sixth day on, with populations reaching up to $10^{9}$ and $10^{8} \mathrm{CFU} \mathrm{ml}^{-1}$ respectively, in fermentations ' $\mathrm{B}$ ' and ' $\mathrm{C}$ ' (Figure 3a1, Figure 3c1). The total yeast community reached up to $10^{9}$ $\mathrm{CFU} \mathrm{m} \mathrm{ml}^{-1}$ in the process ' $\mathrm{B}$ ', but this population was almost completely represented by nonSaccharomyces species, especially Hanseniaspora vineae (Figure 3b2). In the case of fermentation 'C', wild S. cerevisiae strains emerged from the fourth day on, but their representativeness decreased to less than $20 \%$ of the total yeast community within a 48 -hour period (Figure $3 \mathrm{c} 2$ ), followed by dominance of the apiculate $H$. vineae and $H$. opuntiae. When we estimated the frequency of proportional abundance of the yeast species operating in the processes, it was noteworthy the presence of $H$. vineae in fermentation ' $\mathrm{B}$ ', accounting for over $90 \%$ of the ascomycetes community (Figure 3b2) (although Pichia fermentans and Candida spp. were also detected in minor number during the whole process). Even with a prompt presence of fermenting yeasts in fermentation ' $\mathrm{C}$ ', we observed a dominance of the apiculate yeasts, Hanseniaspora opuntiae and $H$. vineae, which mostly prevailed on the whole process (Figure 3ac2). In both cases, Meyerozima guilliermondii was only detected during the early stages of the spontaneous fermentation, while Issatchenkia terricola and Pichia kudriavzevii were only occasionally isolated. 


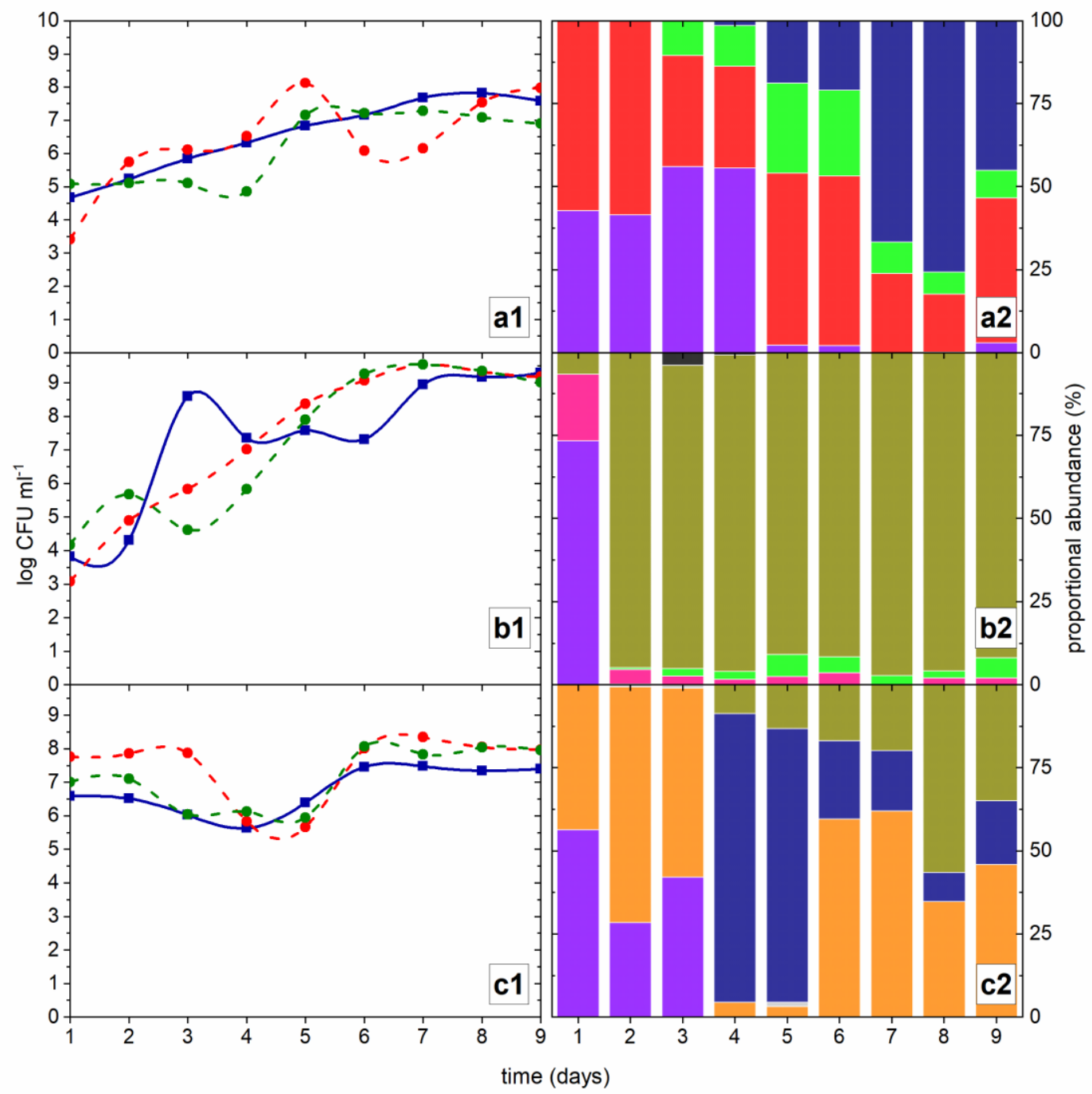

Figure 3. Microbial communities' dynamics and yeast species diversity in spontaneous fermentations. Counting of microbial communities, in colony forming units per $\mathrm{ml}$ $\left(\mathrm{CFU} \mathrm{m}{ }^{-1}\right)$ in batches ' $\mathrm{A}$ ' (a1), 'B' (b1) and ' $\mathrm{C}$ ' (c1): total yeast (blue solid line); lactic acid bacteria (red dashed line); acetic acid bacteria (green dashed line). Frequency of proportional abundance/species richness in batches 'A' (a2), 'B' (b2) and 'C' (c2): Candida spp., - Hanseniaspora guilliermondii, Hanseniaspora opuntiae, Hanseniaspora vineae, - Issatchenkia terricola, Meyerozyma guilliermondii, Pichia fermentans, $\square$ Pichia kudriavzevii, - Saccharomyces cerevisiae.

The analyses of diversity, based on total counting of the yeast species identified within every fermentative process, is represented by the indexes in Table 2. Higher species diversity indexes $(H$ ') were found in fermentation ' $\mathrm{A}$ ' and ' $\mathrm{C}$ ', suggesting that the rapid emergence of $S$. cerevisiae may be directly correlated to the relative abundance of different species in the medium. 
When we compare the Pielou's evenness measure $\left(J^{\prime}\right)$, it is assumed that the advent of such autochthonous fermenting yeasts seems to be connected to microenvironments characterized by lower ecological variation, with a virtual tendency of all species to be equally abundant.

It is worth noting, however, that higher dominance indexes (d) were observed precisely in batches 'B' and 'C' (year 2014), mostly influenced by higher population density of notoriously and potential spoilage yeast species, especially those belonging to the genera Hanseniaspora and Pichia (Figure 3b2 and Figure 3c2). It should be noted that even in case ' $\mathrm{C}$ ', this microbial shift was clearly observed, despite the early emergence of $S$. cerevisiae from the fourth day on (Figure $3 \mathrm{c} 2$ ). Notwithstanding, the early and prompt appearance of native $S$. cerevisiae in fermentation 'A' seems to be closely related to lower species dominance rates and, consequently, we observed a homogeneous population succession in this process, which is in accordance with the physicochemical parameters dynamics related before. When we consider the whole nine-day period assessed, however, the most abundant species were apiculate yeasts belonging to the genus Hanseniaspora (H. guilliermondii, H. vineae and $H$. opuntiae) in all three batches.

Table 2. Diversity indexes of yeast populations in 2013 and 2014 in Piracicaba (São Paulo State, Brazil)

\begin{tabular}{lcccc}
\hline & S & $\mathbf{H}^{\prime}$ & $\mathbf{d}$ & $\mathbf{J}^{\prime}$ \\
\cline { 2 - 5 } A (2013) & 4 & 0.5641 & $0.3378^{\mathbf{a}}$ & 0.9369 \\
B (2014) & 5 & 0.1428 & $0.9323^{\mathbf{b}}$ & 0.2043 \\
C (2014) & 5 & 0.5352 & $0.4874^{\mathbf{c}}$ & 0.7657
\end{tabular}

Calculations using base-10 logarithm. (S) richness/number of species, (H') Shannon index, (J') Pielou evenness index, (d) Berger-Parker dominance, indicating the dominating species: ${ }^{\mathbf{a}} \mathrm{H}$. guillermondii ('A'); ${ }^{\mathbf{b}} \mathrm{H}$. vineae ('B'); ${ }^{\mathbf{c}} \mathrm{H}$. opuntiae ('C').

Divergences in the structure and dynamics of the microbial communities were confirmed by T-RFLP analysis in all three fermentations studied (Figure 4). The principal coordinate analysis shows that the fungal community in the process ' $A$ ' showed greater differentiation compared to ' $\mathrm{B}$ ' and ' $\mathrm{C}$ ' (separated in the first axis, which explains $52.31 \%$ of the variance observed) (Figure 4a). Comparing the structure of the bacterial communities (Figure 4b), it is possible to observe similar differences between the three processes. The corresponding hierarchical cluster analysis performed in both cases (right side in Figure 4a and Figure 4b) confirm stronger similarities (67$75 \%$ ) of fungal and bacterial community structures for those fermentations carried out in 2014, as opposed to fermentation ' $A$ '. 


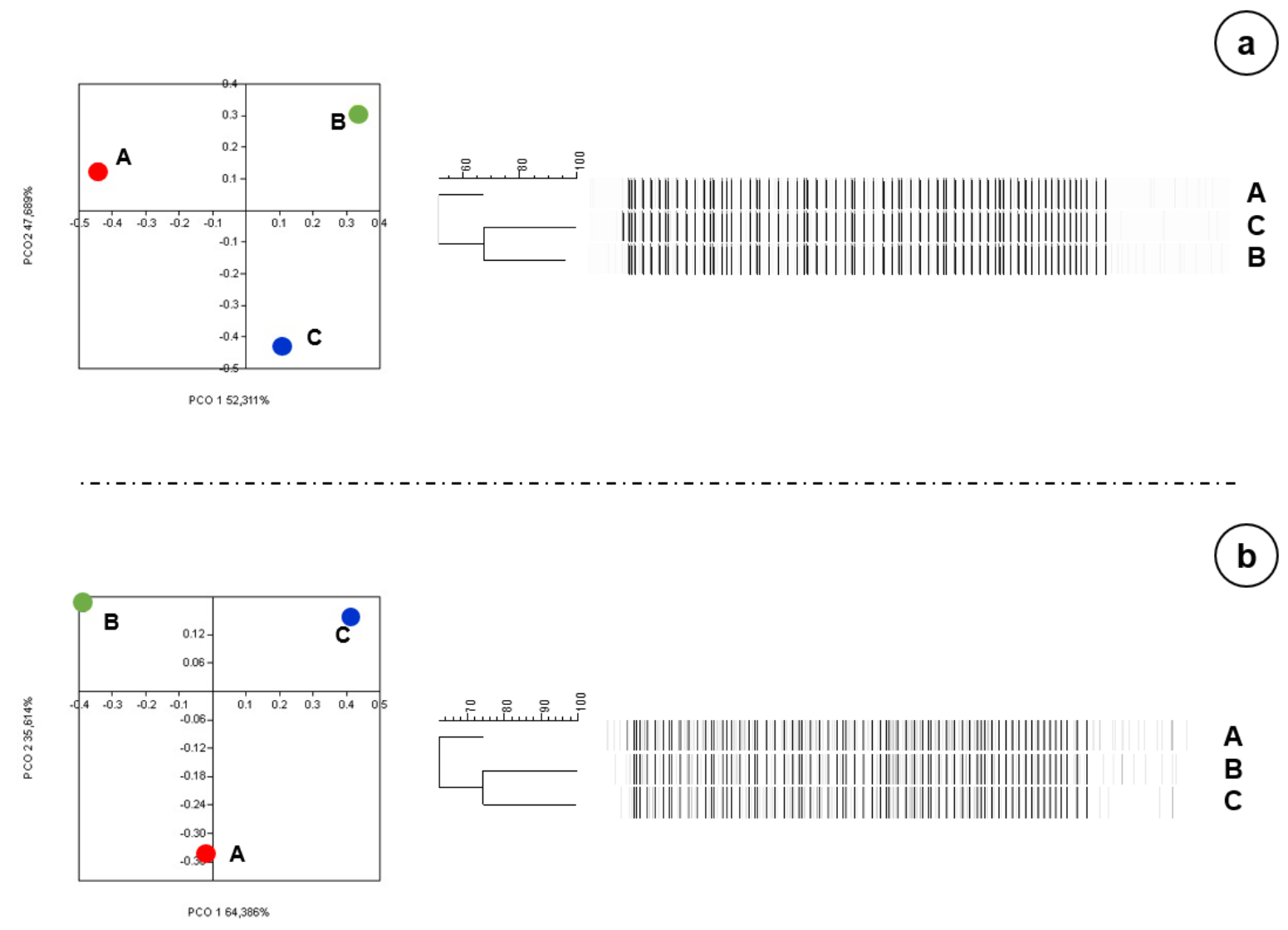

Figure 4. Microbial community profiles in cachaça's sugarcane fermentations. In parallel, principal coordinate analysis (left) and hierarchical clustering analysis (right) of fungal (a) and bacterial (b) communities. Similarity branches in cluster analysis established from $0 \%$ to $100 \%$.

\section{DISCUSSION}

In the Southeast region of Brazil, 2014 was the driest year since 2003 (13\% below the reported climatological average), with temperature high scores of up to $37.2^{\circ} \mathrm{C}$ (IAG/USP, 2014). The months that preceded the 2014 sugarcane harvest - beginning in April - showed the lowest precipitation rates, which in combination to higher temperatures - and also $\mathrm{CO}_{2}$ concentration performs a serious shock of drought stress for long cycle crops, with direct consequences in key physiological processes of the plant (SINGELS et al., 2014). The hydric stress may disturb the population of diazotrophic microorganisms, because in soils with progressive water deficit, sugarcane plants tend to display low levels of acetylene reduction, associated with a lower number of root-commensal microorganisms and loss of nitrogen fixation (REIS JÚNIOR et al., 2004). In 
this study case, both fermentations monitored in 2014 showed assimilable nitrogen concentrations far below the minimum recommended for a healthy fermentation, which is supposed to be around $100 \mathrm{mg} \mathrm{N}^{\mathbf{- 1}}$ (VIDAL et al., 2013). Nitrogen is a key-limiting nutrient for cell growth, so that deficiency of nitrogenous compounds may be one of the main causes of sluggish fermentations, once yeast cells must alternatively intensify the biosynthesis of essential amino acids (KELKAR \& DOLAN, 2012). On the other hand, the lack of yeast-useful nitrogen may be also correlated to excessive higher alcohols due to downregulation of decarboxylase/dehydrogenase coding-genes, as well as low acetate/acyl esters content in the distilled products (VIDAL et al., 2013).

Sugarcane juice with nutritional shortage also allows the rapid growth of other lessdemanding microorganisms, which ultimately inhibit the development of those autochthonous $S$. cerevisiae (MEDINA et al., 2012). Although certain diazotrophic bacteria (e.g. Bacillus spp. and Gluconacetobacter spp.) figure out as plant growth-promoting members (DE SOUZA et al., 2016), they can also arise as frequent spoilers in sugarcane juice fermentations, promoting intense acidification of the medium and consequent yeast cell damage (ALCARDE et al., 2002). High acidity level is one of the direct consequences from bacterial spoilage in distilled spirits, and it has a direct and negative impact on the organoleptic quality of the product. Even considering that total acidity could change according to some variables, such as sugarcane variety, temperature and management practices (MORAIS et al., 1997), excessive levels could also be another sequel of nitrogen-deficient juices, since acetic acid production may be inversely correlated to YAN levels in the medium (BELY et al., 2003).

In our study, the apiculate yeasts, Hanseniaspora opuntiae and $H$. vineae, stood out for its prominence and persistence in those sluggish/stuck fermentations carried out in 2014. Both organisms are common inhabitants of fruits, frequently occurring in the earlier stages of fermentative processes (WANG \& LIU, 2013, VIANA et al., 2008), and have already been isolated from sugarcane fermentations (SILVA et al., 2009, PORTUGAL et al., 2016). The species $H$. opuntiae was reported to dominate fermentations of cocoa beans (PAPALEXANDRATOU et al., 2013) and grape marcs (BOVO et al., 2009), but to date, this is the first time it is reported as a prevailing species in the production of cachaça. Despite the fact that these yeasts display a restrained fermentative fitness, and their early proliferation may inhibit S. cerevisiae, they can contribute with enzymatic reactions and distinctive flavor metabolites in the initial stages of welldriven processes (PORTUGAL et al., 2017). Recent studies have suggested mixed inoculation with 
these species to improve flavor complexity (MEDINA et al., 2013, ASSIS et al., 2014), but in the case of faulty fermentations, they are indeed related to microbial spoilage and consequent flavor impairment. Non-Saccharomyces yeasts, including those of the genus Hanseniaspora/Kloeckera, are known to commonly dominate the early stages of spontaneous fermentation, and they may exert a positive impact on the flavor profile of the final product (MARTIN et al., 2016). Nevertheless, as demonstrated here, that seems to be true only in the case of matrices with higher diversity indexes and with microbial clusters acting in balanced environments (PORTUGAL et al., 2017), which therefore will result in depletion of essential nutrients and minimize the risk of spoilage (CARRAU et al., 2015, MEDINA et al., 2012). Under abnormal conditions, the overgrowth and dominance of some wild yeast species may also exert a negative role during fermentation, leading to impairment on distillate's quality, such as acetic acid and ester taints (DU TOIT \& PRETORIUS, 2000).

In fact, competition for nutrients may directly influence fermentation kinetics, and consequently, the dynamics of microbial populations in the process (MEDINA et al., 2012). However, current investigations reveal that deviations can also arise from eventual weather anomalies, with direct impact on ecosystems, inducing punctual microbiota shifts, or even changes in the use of human lands and consequent habitat loss (HANNAH et al., 2013). Although the geographical origin and other site-specific variables directly shape the structure of the microbiota in human-associate bioprocesses (BOKULICH et al., 2014), sharp warming events related to global climate change have the potential to quickly modify the microbiogeographical patterns (ZOGG et al., 1997). In the case of sugarcane plants, soil is considered the primary source of microbial colonizers (DE SOUZA et al., 2016), wherein the fungal community structure seems to be mostly influenced by environmental parameters (GUMIERE et al., 2016), while soil traits and management practices are the main determining factors influencing bacterial communities shifts (DURRER et al., 2017). These latter findings seem to be in accordance with our results and shed light on the fact that manifestation of some stressful weather factors can play a primary role in determining the structure of microbial communities in cachaça fermentations.

In Brazil, the largest expansion areas of sugarcane are in the Southeast region, where it is estimated a notorious increase in the occurrence of extreme weather events. It is assumed that random scenarios of stronger weather deviations may be affecting those long-cycle crops, which can be progressively more exposed to untimely risks (MARIN \& NASSIF, 2013). Severe water 
restraint, besides affecting the vegetative growth of the plant, has consequences on the nitrogen fixation by diazotrophic microorganisms in the rhizosphere and gives rise to a nutrient shortage in the sugarcane juice. The lack of ammonium, amino acids, and vitamins is one of the major causes of biomass yield reduction (MARTÍNEZ-MORENO et al., 2012), and such consequent sugar lagging-consumption by yeasts are notorious evidence of harmful physiological and environmental disorders (BISSON, 1999). These sort of stagnant fermentations are fatefully associated to higher levels of residual sugars, allowing the proliferation of undesirable microorganisms, which frequently bring to light unpredictable by-products and off-flavors (MEDINA et al., 2012), or even the direct loss of large production volumes.

In our case study, we considered only one specific area and two investigation cases (under contrasting influences of some weather parameters in subsequent years). The main goal of those findings was to carry out a comparison between the two years and collect practical evidences on microbial community patterns in those fermentations affected by disturbances in ecological patterns. But, finally, an imbalance of microbiogeographical traits is predominantly determined by microbiome shifts that contribute to lower evenness and diversity systems, in addition to higher dominance of potential spoilage microorganisms, resulting on chemical and organoleptic impairment of the resulting distilled product.

\section{CONCLUSION}

Cachaça producers are still searching a proper identity and trying to adapt processing practices without losing the typicality of their products. This leads to urgency on the improvement of the process, which must be straightly adapted against specific weather anomalies to avoid these current microbiological handicaps. This is a preliminary study, but it sheds light on the fact that integrated practices should incorporate the strict control of technical guidelines, but also the prior knowledge of the autochthonous microbial community to promptly detect harmful shifts in its structure in consequence of more predictable edaphoclimatic disorders. Preventive and accurate detection of the hotspots causing slow and incomplete fermentations are imperative to ensure the mitigation of stressful parameters, ensuring chemical and organoleptic improvement, besides preserving the traits of typicality of the authentic Brazilian sugarcane spirit, cachaça. 


\section{ACKNOWLEDGMENTS}

To the São Paulo Research Foundation (grant number 2013/03766-4). Thanks to Rosemary da Silva, Sylvino Torrezan, and Pedro Lucentini for the technical support on analyses. We appreciate the collaboration of Dr. Fernando Andreote's team of Soil Microbiology Lab. (ESALQUSP).

\section{REFERENCES}

ALCARDE, A. R., WALDER, J. M. M. \& HORII, J. 2002. Effect of $\gamma$ radiation on physiological parameters of the ethanolic fermentation. World Journal of Microbiology and Biotechnology, Amsterdam, v. 18, p. 41-48.

ASSIS, M. O., SANTOS, A. P. C., ROSA, C. A. \& MAMEDE, M. E. D. O. 2014. Impact of a nonSaccharomyces yeast isolated in the Equatorial region in the acceptance of wine aroma. Food and Nutrition Sciences, London, v. 5, p. 759-769.

BELY, M., RINALDI, A. \& DUBOURDIEU, D. 2003. Influence of assimilable nitrogen on volatile acidity production by Saccharomyces cerevisiae during high sugar fermentation. Journal of Bioscience and Bioengineering, Amsterdam, v. 96, p. 507-512.

BISSON, L. F. 1999. Stuck and sluggish fermentations. American Journal of Enology and Viticulture, Davis, v. 50, p. 107-119.

BOKUliCH, N. A., THORNGATE, J. H., RICHARDSON, P. M. \& MILLS, D. A. 2014. Microbial biogeography of wine grapes is conditioned by cultivar, vintage, and climate. Proceedings of the National Academy of Sciences, Washington, v. 11, p. 139-148.

BOVO, B., ANDRIGHETTO, C., CARLOT, M., CORICH, V., LOMBARDI, A. \& GIACOMINI, A. 2009. Yeast population dynamics during pilot-scale storage of grape marcs for the production of Grappa, a traditional Italian alcoholic beverage. International Journal of Food Microbiology, Amsterdam, v. 129, p. 221-228.

CALDAS, C. 1998. Manual de análises selecionadas para indústrias sucroalcooleiras. Maceió: Sindicato da Indústria do Açúcar e do Álcool do Estado de Alagoas. p. 424.

CARRAU, F., GAGGERO, C. \& AGUILAR, P. S. 2015. Yeast diversity and native vigor for flavor phenotypes. Trends in Biotechnology, Amsterdam, v. 33, p. 148-154.

CULMAN, S. W., GAUCH, H. G., BLACKWOOD, C. B. \& THIES, J. E. 2008. Analysis of T RFLP data using analysis of variance and ordination methods: A comparative study. Journal of Microbiological Methods, Amsterdam, v. 75, p. 55-63.

DE SOUZA, R. S. C., OKURA, V. K., ARMANHI, J. S. L., JORRÍN, B., LOZANO, N., DA SILVA, M. J., GONZÁLEZ-GUERRERO, M., DE ARAÚJO, L. M., VERZA, N. C. \& BAGHERI, H. C. 2016. Unlocking the bacterial and fungal communities assemblages of sugarcane microbiome. Scientific Reports, London, v. 6, p. 28774.

DU TOIT, M. \& PRETORIUS, I. S. 2000. Microbial spoilage and preservation of wine: using weapons from nature's own arsenal - A review. South African Journal of Enology and Viticulture, Stellenbosch, v. 21, p. 74-96.

DURRER, A., GUMIERE, T., TAKETANI, R. G., COSTA, D. P. D., PEREIRA E SILVA, M. D. C. \& ANDREOTE, F. D. 2017. The drivers underlying biogeographical patterns of bacterial communities in soils under sugarcane cultivation. Applied Soil Ecology, Amsterdam, v. 110, p. $12-20$. 
GARDES, M. \& BRUNS, T. D. 1993. ITS primers with enhanced specificity for basidiomycetes application to the identification of mycorrhizae and rusts. Molecular Ecology, London, v. 2, p. 113-118.

GUMIERE, T., DURRER, A., BOHANNAN, B. J. M. \& ANDREOTE, F. D. 2016. Biogeographical patterns in fungal communities from soils cultivated with sugarcane. Journal of Biogeography, New Jersey, v. 43, p. 2016-2026.

HAMMER, Ø., HARPER, D. A. T. \& RYAN, P. D. 2001. Paleontological Statistics Software: Package for Education and Data Analysis. Palaeontologia Electronica, Austin, v. 4, p. 9.

HANNAH, L., ROEHRDANZ, P. R., IKEGAMI, M., SHEPARD, A. V., SHAW, M. R., TABOR, G., ZHI, L., MARQUET, P. A. \& HIJMANS, R. J. 2013. Climate change, wine, and conservation. Proceedings of the National Academy of Sciences, Washington, v. 110, p. 6907-6912.

HUANG, Y.-C., EDWARDS, C. G., PETERSON, J. C. \& HAAG, K. M. 1996. Relationship between sluggish fermentations and the antagonism of yeast by lactic acid bacteria. American Journal of Enology and Viticulture, Davis, v. 47, p. 1-10.

IAG/USP 2014. Boletim Climatológico Anual da Estação Meteorológica do IAG/USP. São Paulo: Instituto de Astronomia, Geofísica e Ciências Atmosféricas, Univ. São Paulo.

KELKAR, S. \& DOLAN, K. 2012. Modeling the effects of initial nitrogen content and temperature on fermentation kinetics of hard cider. Journal of Food Engineering, Amsterdam, v. 109, p. 588-596.

KURTZMAN, C. \& ROBNETT, D. J. 1998. Identification and phylogeny of ascomycetous yeasts from analysis of nuclear large subunit (26S) ribosomal DNA partial sequences. Antonie van Leeuwenhoek, Amsterdam, 73, 331-371.

LEA, A. G. \& PIGGOTT, J. R. 2003. Fermented beverage production. New York: Springer Science \& Business Media, p. 335-344.

MARIN, F. \& NASSIF, D. S. P. 2013. Climate change and the sugarcane in Brazilian: physiology, conjuncture and future scenario. Revista Brasileira de Engenharia Agrícola e Ambiental, Campina Grande, v. 17, p. 232-239.

MARTIN, V., BOIDO, E., GIORELLO, F., MAS, A., DELlACASSA, E. \& CARRAU, F. 2016. Effect of yeast assimilable nitrogen on the synthesis of phenolic aroma compounds by Hanseniaspora vineae strains. Yeast, Oxford, v. 33, p. 323-328.

MARTÍNEZ-MORENO, R., MORALES, P., GONZALEZ, R., MAS, A. \& BELTRAN, G. 2012. Biomass production and alcoholic fermentation performance of Saccharomyces cerevisiae as a function of nitrogen source. FEMS Yeast Research, Oxford, v. 12, p. 477-485.

MEDINA, K., BOIDO, E., DELLACASSA, E. \& CARRAU, F. 2012. Growth of nonSaccharomyces yeasts affects nutrient availability for Saccharomyces cerevisiae during wine fermentation. International Journal of Food Microbiology, Amsterdam, v.157, p. 245-250.

MEDINA, K., BOIDO, E., FARIÑA, L., GIOIA, O., GOMEZ, M. E., BARQUET, M., GAGGERO, C., DELlACASSA, E. \& CARRAU, F. 2013. Increased flavour diversity of Chardonnay wines by spontaneous fermentation and co-fermentation with Hanseniaspora vineae. Food Chemistry, Amsterdam, v.141, p. 2513-2521.

MILLER, G. L. 1959. Use of dinitrosalicylic acid reagent for determination of reducing sugar. Analytical Chemistry, Washington, v. 31, p. 426-428.

MORAIS, P. B., ROSA, C. A., LINARDI, V. R., PATARO, C. \& MAIA, A. B. R. A. 1997. Characterization and succession of yeast populations associated with spontaneous fermentations during the production of Brazilian sugar-cane aguardente. World Journal of Microbiology and Biotechnology, New York, v. 13, p. 241-243. 
MUNOZ, E. \& INGLEDEW, W. M. 1989. Effect of yeast hulls on stuck and sluggish wine fermentations: importance of the lipid component. Applied and Environmental Microbiology, Washington, v. 55, p. 1560-1564.

PAPALEXANDRATOU, Z., LEFEBER, T., BAHRIM, B., LEE, O. S., DANIEL, H.-M. \& DE VUYST, L. 2013. Hanseniaspora opuntiae, Saccharomyces cerevisiae, Lactobacillus fermentum, and Acetobacter pasteurianus predominate during well-performed Malaysian cocoa bean box fermentations, underlining the importance of these microbial species for a successful cocoa bean fermentation process. Food Microbiology, Amsterdam, v. 35, p. 73-85.

PORTUGAl, C. B., AlCARDE, A. R., BORTOLETTO, A. M. \& DE SILVA, A. P. 2016. The role of spontaneous fermentation for the production of cachaça: a study of case. European Food Research and Technology, Berlin, v. 242, p. 1587-1597.

PORTUGAL, C. B., DE SILVA, A. P., BORTOLETTO, A. M. \& ALCARDE, A. R. 2017. How native yeasts may influence the chemical profile of the Brazilian spirit, cachaça? Food Research International, Burlington, v. 91, p. 18-25.

REIS JÚNIOR, F., SILVA, M., TEIXEIRA, K., URQUIAGA, S. \& REIS, V. 2004. Identificação de isolados de Azospirillum amazonense associados a Brachiaria spp., em diferentes épocas e condições de cultivo e produção de fitormônio pela bactéria. Revista Brasileira de Ciência do Solo, Viçosa, v. 28, p. 103-113.

SENGAR, K., SENGAR, R. S., LAL, K. \& RAO, V. P. 2014. Climate change effect on sugarcane productivity. In: SENGAR, R. S. \& SENGAR, K. (eds.) Climate change effect on crop productivity. Florida: CRC Press, p. 177-185.

Silva, C. L. C., VIANNA, C. R., CADETE, R. M., SANTOS, R. O., GOMES, F. C. O., OLIVEIRA, E. S. \& ROSA, C. A. 2009. Selection, growth, and chemo-sensory evaluation of flocculent starter culture strains of Saccharomyces cerevisiae in the large-scale production of traditional Brazilian cachaça. International Journal of Food Microbiology, Amsterdam, v. 131, p. 203-210.

SINGELS, A., JONES, M., MARIN, F., RUANE, A. \& THORBURN, P. 2014. Predicting climate change impacts on sugarcane production at sites in Australia, Brazil and South Africa using the Canegro model. Sugar Tech, New Delhi, v. 16, p. 347-355.

VERDENAL, T., ZUFFEREY, V., BURGOS, S., RÖSTI, J., LORENZINI, F., DIENES-NAGY, A., GINDRO, K., SPRING, J.-L. \& VIRET, O. 2014. The effect of pedoclimatic conditions on the yeast assimilable nitrogen concentration on white cv. Doral in Switzerland. In: XII INTERNATIONAL TERROIR, Tokaj, 07-10 July, 2014. Proceedings.

CONGRESSO BRASILEIRO DE MELHORAMENTO DE PLANTAS, 1., Goiânia, GO, 03 a 06 de abril, 2001. Anais. Goiânia: Embrapa Arroz e Feijão. (Embrapa Arroz e Feijão. Documentos, 113).

VERDI, A. R., 2006. Dinâmicas e perspectivas do mercado da cachaça. Informações Econômicas, São Paulo, v. 36, p. 93-98.

VIANA, F., GIL, J. V., GENOVÉS, S., VALLÉS, S. \& MANZANARES, P. 2008. Rational selection of non-Saccharomyces wine yeasts for mixed starters based on ester formation and enological traits. Food Microbiology, Amsterdam, v. 25, n. 6, p. 778-785.

VIDAL, E. E., DE BILLERBECK, G. M., SIMÕES, D. A., SCHULER, A., FRANÇOIS, J. M. \& DE MORAIS JR, M. A. 2013. Influence of nitrogen supply on the production of higher alcohols/esters and expression of flavour-related genes in cachaça fermentation. Food Chemistry, Amsterdam, v. 138, p. 701-708.

WANG, C. \& LIU, Y. 2013. Dynamic study of yeast species and Saccharomyces cerevisiae strains during the spontaneous fermentations of Muscat blanc in Jingyang, China. Food Microbiology, Amsterdam, v. 33, p. 172-177. 
WHITE, T., BRUNS, T., LEE, S. \& TAYLOR, J. 1990. Amplification and direct sequencing of fungal ribosomal RNA genes for phylogenetics. In: INNIS, M., GELFAND, D., SHINSKY, J. \& WHITE, T. (eds.) PCR Protocols: A Guide to Methods and Applications. San Diego: Academic Press, p. 315-324.

ZOECKLEIN, B. W., FUGELSANG, K. C. \& GUMP, B. H. 1995. Wine analysis and production. Bruxels: Kluwer Academic Publishers, p. 474-477.

ZOGG, G. P., ZAK, D. R., RINGELBERG, D. B., WHITE, D. C., MACDONALD, N. W. \& PREGITZER, K. S. 1997. Compositional and functional shifts in microbial communities due to soil warming. Soil Science Society of America Journal, Madison, v. 61, p. 475-481. 